Anais da Academia Brasileira de Ciências (2006) 78(1): 151-173

(Annals of the Brazilian Academy of Sciences)

ISSN 0001-3765

www.scielo.br/aabc

\title{
The Tectonic interaction between the Paramirim Aulacogen and the Araçuaí Belt, São Francisco craton region, Eastern Brazil
}

\author{
SIMONE C.P. CRUZ and FERNANDO F. ALKMIM \\ Universidade Federal de Ouro Preto, Departamento de Geologia, Campus Morro do Cruzeiro \\ 35400-000 Ouro Preto, MG, Brasil \\ Manuscript received on January 5, 2005; accepted for publication on August 4, 2005; \\ presented by ALCIDES N. SIAL
}

\begin{abstract}
The Paramirim aulacogen, hosted in the northern part of the São Francisco craton, corresponds to two superimposed and partially inverted rifts of Paleo and Neoproterozoic ages. The Rio Pardo salient of the Araçuaí belt defines the local limit of the craton and interferes with the aulacogen structures. In order to understand the mechanism and timing of the tectonic interaction between these tectonic features during the inversion processes, a structural analysis was undertaken in the southern Paramirim aulacogen and along the Rio Pardo salient. The results obtained indicate that the Rio Pardo salient formed during an early stage of closure of the Neoproterozoic Macaúbas rift system and consequent initiation of the Araçuaí orogen. The orogenic front propagated further northwards into the craton, causing a first stage of inversion in the southern terminus of the aulacogen trough. Subsequently, the Paramirim aulacogen experienced the main stage of inversion, which led to the development of a NNW-oriented basement involved fold-thrust system. These fabric elements overprint the Rio Pardo salient, and the structures of both the first and second stages of inversion affect the Salitre Formation, the youngest Neoproterozoic unit of the area, clearly indicating a Late Neoproterozoic maximum age for all the inversion stages of the Paramirim aulacogen.
\end{abstract}

Key words: Araçuaí-West Congo orogen, Araçuaí belt, Paramirim aulacogen, Brasiliano event.

\section{INTRODUCTION}

The São Francisco craton in eastern Brazil is almost entirely covered by Precambrian and Phanerozoic successions. The covered domains of the craton interior comprise two distinct morphotectonic units: the Paramirim aulacogen to the north, and the São Francisco basin to the south (Fig. 1).

The tectonic feature here referred to as the Paramirim aulacogen (after Pedrosa Soares et al. 2001), originally defined and named "Espinhaço

Correspondence to: Simone Cerqueira Pereira Cruz E-mail: Simone@geologist.com; simone@ degeo.ufop.br aulacogen" by Costa and Inda (1982), encompasses the region of the northern Espinhaço range, the Paramirim and São Francisco river valleys, as well as the large interior plateau of the Chapada Diamantina in Bahia (Fig. 1). The Paramirim aulacogen corresponds to two superimposed and partially inverted intracratonic rift basins, that involve two major lithostratigraphic units, namely the Espinhaço and São Francisco supergroups of Paleo/Mesoproterozoic and Neoproterozoic ages, respectively (Schobbenhaus 1996). 


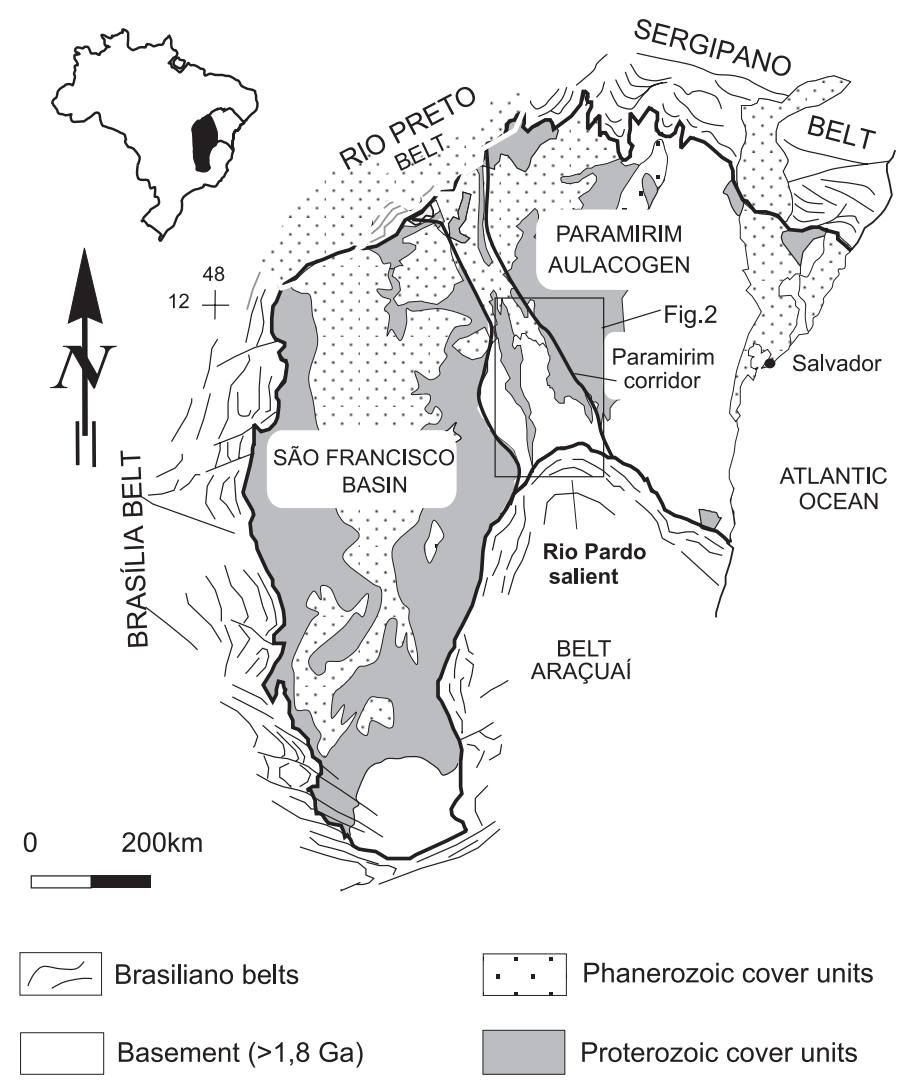

Fig. 1 - Simplified geologic map of the São Francisco craton showing the Paramirim aulacogen, the Paramirim corridor and the Araçuaí belt. The box indicates the location of Figure 2 (Based on Alkmim et al. 1993).

A substantial part of the Paramirim aulacogen, especially the portions close to the craton boundaries, shows the effects of tectonic inversion (Schobbenhaus 1996, A. Danderfer $F^{\circ}$, unpublished data, L.E. Lagoeiro, unpublished data, Alkmim et al. 1993, 1996). However, the area of maximal inversion strains in the aulacogen defines a ca. $200 \mathrm{~km}$ wide corridor, the Paramirim deformation corridor, that cuts across the craton in the NNW direction (Alkmim et al. 1993) (Fig. 1).

The Neoproterozoic Araçuaí belt (Almeida 1977) fringes the São Francisco craton to the southeast. The northern segment of the Araçuaí belt exhibits a pronounced curvature in map view (Almeida 1977), which is here referred to as the Rio Pardo salient. The Rio Pardo salient interacts with the southern terminus of the perpendicularly oriented
Paramirim corridor, thereby creating an interference zone (Fig. 1).

In this paper we present the results of a detailed structural analysis conducted in the interference zone between the southern Paramirim corridor and the large salient displayed by the Araçuaí belt along the southeastern border of the São Francisco craton (Fig. 1). This specific area was chosen for study because it contains very good exposures of critical units and structures, allowing us to address four key questions regarding the tectonic history of both the Paramirim aulacogen and the Araçuaí belt. These questions are: $i$ ) how deformation is accommodated in the inverted portions of the Paramirim aulacogen; $i$ ) how the Paramirim corridor interferes with the Araçuaí belt; iii) what is the age of the inversion of the aulacogen; $i v$ ) which mechanism drove 
the inversion. In the following sections, after outlining the geology of the study area, we describe the main structures of both the southern Paramirim corridor and Rio Pardo salient of the Araçuaí belt, emphasizing their crosscutting relationships. We conclude by bringing new insights on the mechanisms and the age of the inversion of the Paramirim aulacogen - Neoproterozoic or younger, according to our results -, a matter of long debate in the Brazilian geologic literature.

\section{TECTONIC SETTING}

The São Francisco craton is defined as one of the portions of the South American platform that escaped the effects of the Brasiliano orogenies in the Neoproterozoic (Almeida 1977). The São Francisco craton and other portions of South America and Africa represent the nuclei of the continental plates that collided to form West Gondwana by the end of the Neoproterozoic (Brito Neves et al. 1999, Campos Neto 2000, Alkmim et al. 2001). Thus, the various cratons of South America and Africa are amalgamated by a network of Neoproterozoic orogens that define the so called Brasiliano/PanAfrican tectonic collage (Trompette 1994, Campos Neto 2000).

Except for the Atlantic margin, the São Francisco craton has its boundaries defined by the Neoproterozoic Brasília, Rio Preto, Riacho do Pontal, Sergipano and Araçuaí fold-thrust belts (Fig. 1). These belts correspond to the external domains of the Tocantins province, to the west, Borborema strike-slip province, to the north, and Araçuaí-West Congo orogen, to the east-southeast.

The basement of the São Francisco craton comprises Archean and Paleoproterozoic rocks older than $1.8 \mathrm{Ga}$ (Almeida 1977). Much of the craton interior is covered by younger sedimentary units, which occur in two distinct morphotectonic domains, the Paramirim aulacogen and São Franciso basin (Fig. 1). The Precambrian fill units of the Paramirim aulacogen and São Francisco basin are the Paleo/Mesoproterozoic Espinhaço and the Neoproterozoic São Francisco supergroups.
The Araçuaí belt (Almeida 1977) that defines the eastern limit of the São Francisco craton (Fig. 1) involves an Archean basement, Paleoproterozoic plutonic rocks, as well as Proterozoic cover units (the Espinhaço and São Francisco supergroups) (Dussin and Dussin 1995, Uhlein et al. 1999). In recent studies, the Araçuaí belt is portrayed as the external metamorphic belt of the Araçuaí-West Congo orogen, a tongue-shaped orogenic domain, developed between the São Francisco and Congo cratons, during the assembly of West Gondwana in the Neoproterozoic (Pedrosa Soares et al. 1992, 1998, 2001).

\section{THE PARAMIRIM AULACOGEN}

\section{STRATIGRAPHY}

The basement of the Paramirim aulacogen, consisting of Archean TTG's, Paleoproterozoic metasedimentary rocks and granitoids, represents a segment of a roughly NS-trending Paleoproterozoic collisional orogen, the Itabuna belt (Figueiredo 1989, Barbosa 1990, Teixeira and Figueiredo 1991, Barbosa and Fonteilles 1993, Figueiredo and Barbosa 1993, Barbosa and Sabaté 2002). The main exposure area of the basement within the aulacogen is the Paramirim valley, where a block of Archean TTG's bounded by reverse faults on both sides was brought on top of the Espinhaço Supergroup metasedimentary rocks (Fig. 2).

A substantial number of $\mathrm{K}-\mathrm{Ar}$, and more recently, Ar-Ar age determinations have been undertaken in the basement rocks of the Paramirim aulacogen (e.g., F.J. Távora et al., unpublished data, Cordani et al. 1985, 1992, Mascarenhas and Garcia 1989, Wilson et al. 1988, Teixeira 1993, Bastos Leal et al. 1998, 2000). Two clusters of ages can be recognized among these data: 1.9-1.8 Ga and 0.9-0.5 Ga. The older are interpreted as cooling ages related to a Paleoproterozoic tectonic event; the younger as the Neoproterozoic Brasiliano resetting.

Along the Paramirim valley, Paleoproterozoic plutonic rocks of the Lagoa Real Complex (Costa et al. 1985) intrude the Archean TTG's. The Lagoa 


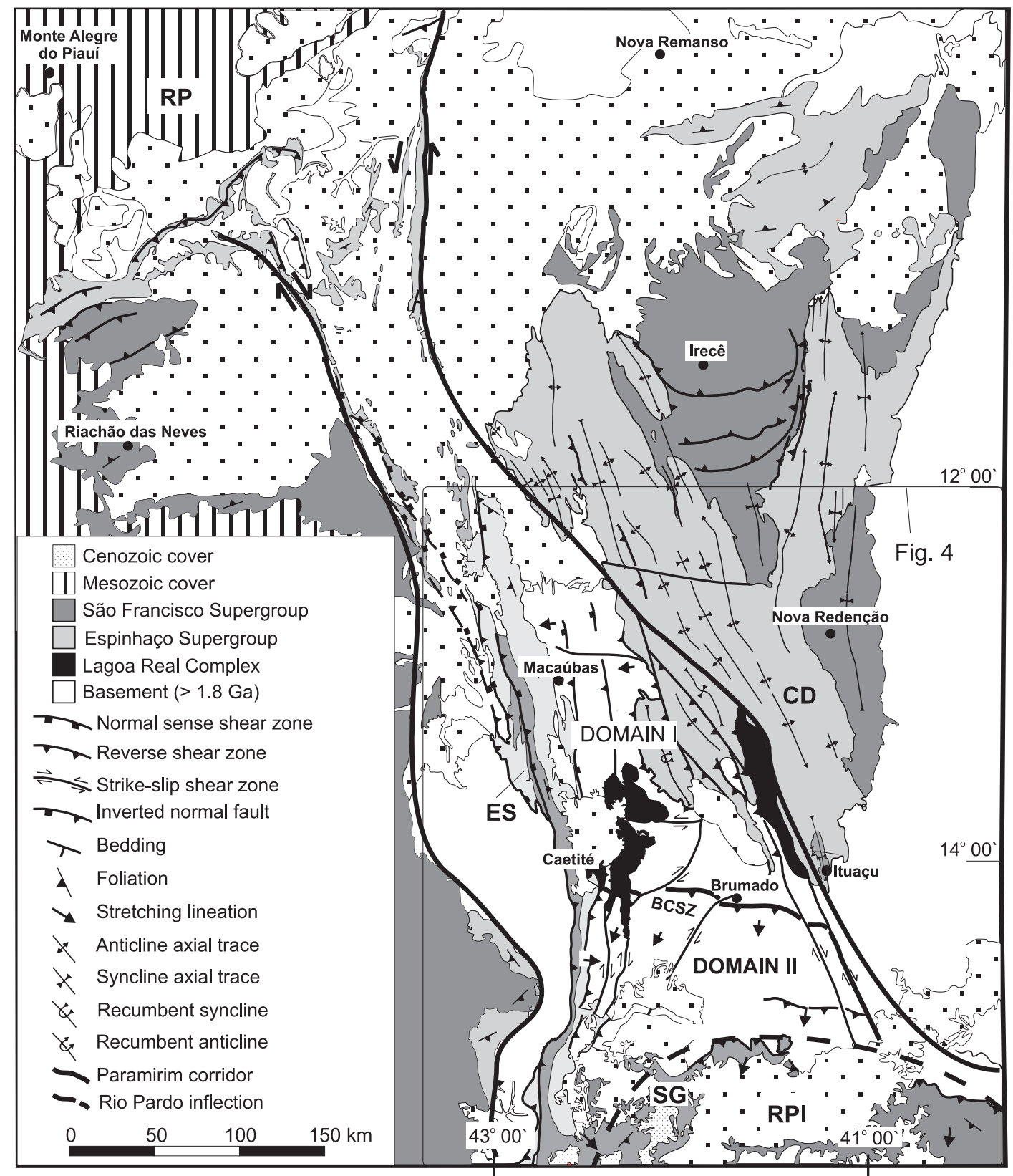

Fig. 2 - Simplified geologic map of the Paramirim aulacogen. The box indicates the location of Figure 4 (Based on Schobbenhaus et al. 1981, Barbosa and Dominguez 1996, A. Danderfer $\mathrm{F}^{\circ}$, unpublished data). BCSZ - Brumado-Caetité shear zone, ES - Espinhaço Setentrional, CD - Chapada Diamantina, RP - Rio Preto belt, RPI - Rio Pardo salient of the Araçuaí belt, SG - Serra Geral range.

Real Complex is composed of alkali-gneisses and granitoids (Maruèjol et al. 1987, Lobato and Fyfe 1990), among them the São Timóteo Granite. These rocks yield crystallization ages around $1.7 \mathrm{Ga}$ (Maruèjol et al. 1987, Turpin et al. 1988, Cordani et al. 1985, 1992, M.M. Pimentel et al., unpublished data). Using the U-Pb method in uraninite extracted from the gneisses and albitites of the Lagoa Real Complex, J.H. Stein et al. (unpublished data) obtained concordant ages around $820 \mathrm{Ma}$. On the other 
hand, discordant zircon U-Pb ages around $500 \mathrm{Ma}$ have been interpreted by Turpin et al. (1988) as the age of metamorphism of the Lagoa Real rocks. These authors also found $\mathrm{U}-\mathrm{Pb}$ ages in uraninite of 1350 and 480 Ma. Cordani et al. (1992) studied the $\mathrm{Rb}$-Sr system of the Lagoa Real Complex, which yield ages of 1520, 1220 and 1000 Ma. K-Ar dates by the same authors fall between 570 and 490 Ma. M.M. Pimentel et al. (unpublished data) dated zircons and sphene grains of the Lagoa Real Complex. The discordant ages obtained have an upper intercept at $1740 \mathrm{Ma}$ and a lower intercept at $490 \mathrm{Ma}$. An upper intercept at $960 \mathrm{Ma}$ was also obtained from sphene grains by the same author.

The fill units of the Paramirim aulacogen reflect a series of events in which the lithospheric fragment of the present-day São Francisco craton and its margins were involved after $1.8 \mathrm{Ga}$. The oldest among these events is the Espinhaço rifting or Statherian taphrogenesis, recorded by the $1.75 \mathrm{Ga}$ volcano-sedimentary basal units of the Espinhaço Supergroup (Brito Neves et al. 1996, Schobbenhaus 1996). The Espinhaço Supergroup is made up of a thick quartz-arenite dominated package containing acid and basic volcanics at the base. The basal units, essentially alluvial, are separated from the aeolian to shallow marine upper units by an unconformity, that marks the rift/post-rift subsidence phases (Dominguez 1993, 1996, Danderfer $\mathrm{F}^{\circ}$ and Dardenne 2002). Remarkable facies changes have been documented between the northern Espinhaço range and the Chapada Diamantina, the two main occurrence areas of the Espinhaço Supergroup in the Paramirim aulacogen (Dominguez 1993, 1996, Danderfer $\mathrm{F}^{\circ}$ and Dardenne 2002). The stratigraphic subdivisions of the Espinhaço Supergroup in these areas are shown on Figure 3. These facies changes result from a pronounced asymmetry of the original geometry of the Espinhaço rift (Alkmim et al. 1993, Schobbenhaus 1996, Danderfer $\mathrm{F}^{\circ}$ and Dardenne 2002).

The Santo Onofre Group in the northern Espinhaço range, and the Bebedouro Formation in the Chapada Diamantina (Fig. 3), as correlatives of the
Macaúbas Group of presumable Tonian age 950$850 \mathrm{Ma}$ (Macedo and Bonhomme 1984, Schobbenhaus 1996, Danderfer $\mathrm{F}^{\circ}$ and Dardenne 2002) are in both areas the manifestation of a second phase of rifting in a glacially influenced environment, reflecting the dispersal of Rodinia (Pedrosa Soares et al. 1998, 2001, Brito Neves et al. 1999, Campos Neto 2000, Alkmim and Martins Neto 2001). The Bebedouro Formation, separated from the Espinhaço Supergroup by a pronounced unconformity, consists of diamictites, pelites and sandstones, which have been interpreted as glaciomarine deposits (J.T. Guimarães, unpublished data). According to Danderfer $\mathrm{F}^{\circ}$ and Dardenne (2002), the thick turbiditic package of the Santo Onofre Group was deposited in a dextral pull-apart branch of the Macaúbas rift system. The Macaúbas rift system as a whole was composed of the Paramirim ensialic arm linked to a Red Sea type ocean, whose closure led to the generation of the Araçuaí-West Congo orogen in the Neoproterozoic (Pedrosa Soares et al. 1992, 1998, 2001, Tack et al. 2001).

The probably Cryogenian Bambuí Group of the São Francisco basin and its correlative Salitre Formation of the Chapada Diamantina mark a general sea level rise and the foreland behavior and local inversion imposed on the craton interior by a series of diachronic collisions that led to the development of the belts around the São Francisco craton in the time interval of 720-580 Ma (Martins Neto and Alkmim 2001). According to Macedo and Bonhomme (1984), the deposition of the Salitre Formation took place between 750 and $850 \mathrm{Ma}$, as indicated by $\mathrm{Rb} / \mathrm{Sr}$ ages obtained in pelitic rocks. The signatures of $\mathrm{C}, \mathrm{S}, \mathrm{O}$, and $\mathrm{Sr}$ isotopes of the basal units of the correlative Bambuí Group match with those obtained in the Maieberg cap carbonate of Namibia, possibly indicating their deposition in the aftermath of a global glacial event (Misi 2001).

\section{Geologic ARCHItecture AND THE} PARAMIRIM CORRIDOR

The regional architecture of the Paramirim aulacogen is dominated by NNW-trending fabric ele- 


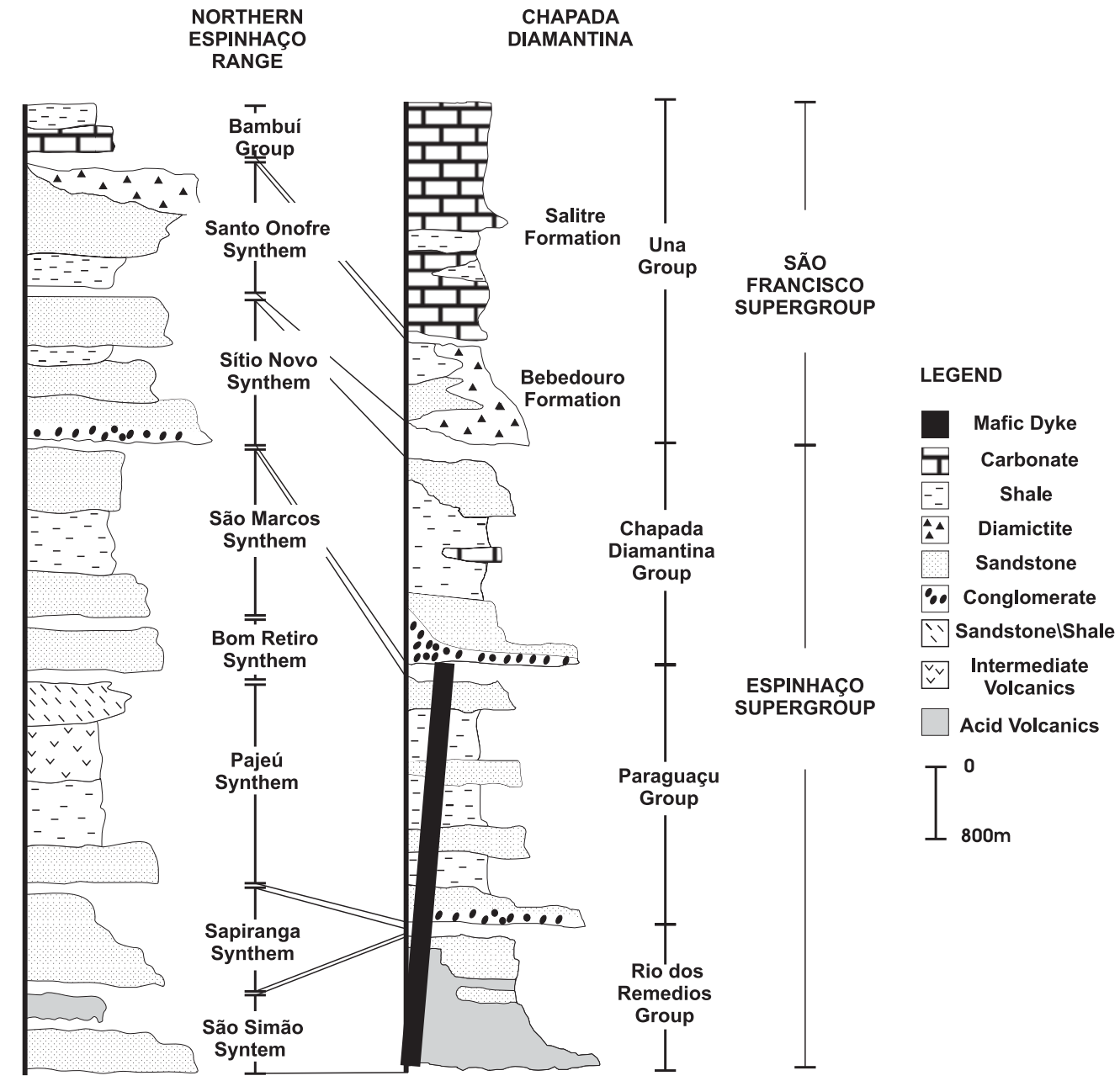

Fig. 3 - Schematic stratigraphic columns for the Chapada Dimantina and northern Espinhaço range (Based on A. Danderfer $\mathrm{F}^{\circ}$, unpublished data).

ments (Fig. 2), which to a large extent correspond to inverted rift structures. The most intensively deformed area of the aulacogen forms the Paramirim corridor that cuts across the craton in NNW direction (Fig. 2). The spatial distribution of the fill units of the aulacogen indicates that this deformation corridor coincides with the deepest portion of the original superimposed rifts (Alkmim et al. 1993).

Two segments of distinct geologic architecture and tectonic evolution can be recognized along the Paramirim corridor. The northern segment comprises the interaction zone with the marginal Rio Preto belt and the portion of the aulacogen that escaped the inversion processes (A. Danderfer $\mathrm{F}^{\circ}$, unpublished data) (Figs. 1 and 2). The southern segment, exposed in the area to the south of the São Francisco river valley, includes the interference zone with the Araçuaí belt and represents the structurally most complex portion of the aulacogen. The structural picture of part of the southern segment resembles a gigantic flower structure, in which two embryonic fold-thrust belts of opposite vergences root in the basement-involved Paramirim deformation corridor. The fold-thrust systems linked to the southern Paramirim corridor are exposed in the Chapada Diamantina and in the NE border of the São Francisco basin (Alkmim et al. 1993, 1996) (Fig. 2). 
The dominant NNW-trending structures interfere with other generations of tectonic elements on both the northern and southern portions of the Paramirim aulacogen. South verging thrusts and folds deform the NNW-trending structures in the northern Chapada Diamantina, thereby creating large scale interference patterns, as shown on the map of Figure 2. Notably, within the preexistent Irecê syncline in the central Chapada Diamantina, carbonates of the Salitre Formation are detached from the underlying Espinhaço quartzites and involved in a southverging imbricate fan of curved thrusts (Fig. 2) (L.A. Lagoeiro, unpublished data, A. Danderfer $\mathrm{F}^{\circ}$, unpublished data). Although not evident in maps, small scale north-verging faults and folds are overprinted by the NNW-trending structures along the southern border of the Chapada Diamantina, as described in more detail in the fourth section of this paper.

\section{Previous Models For the Generation}

AND INVERSION OF THE PARAMIRIM

\section{Aulacogen}

Various models have been postulated to explain the tectonic evolution of the Paramirim aulacogen. Some of the models are incompatible with the existence of the São Francisco craton as defined by Almeida (1977). Consequently, a major debate among geologists working in the Brazilian shield started already by the end of the 70's and has lasted ever since.

Almeida (1977) pointed out that the contractional fabric elements observed along the northern Espinhaço range, Paramirim valley and Chapada Diamantina formed during a "Middle" Precambrian intracratonic deformational event, therefore older than the "Upper" Precambrian Brasiliano belts that define the craton boundaries.

To a group of authors, starting with U.G. Cordani (unpublished data), the deformation of the basement and cratonic cover along the Paramirim and São Francisco valleys characterizes a Brasiliano mobile belt. Consequently, the São Francisco craton concept would not apply. U.G. Cordani (unpub- lished data) postulated the existence of two independent cratons, the São Francisco craton to the westsouthwest, and the Salvador craton to the east, separated by the mobile belt, which would coincide with the regional feature presently known as Paramirim corridor. This interpretation, with some modifications, was later re-invoked by various authors (e.g., Caby and Arthaud 1987, Trompette et al. 1992).

E.F. Jardim de Sá (unpublished data) suggested that the fold-thrust system of the aulacogen resulted from the differential uplift of the Paramirim basement block in respect to the adjacent domains. Costa and Inda (1982) firstly portrayed the tectonic features of the northern Espinhaço range and Chapada Diamantina as a deformed aulacogen. These authors also provide a sophisticated description of the structures involving the Paramirim basement block and adjacent supracrustal units, emphasizing the propeller shape of the reverse fault on the east side of the northern Espinhaço range.

According to A. Danderfer $\mathrm{F}^{\circ}$ (unpublished data) and L.E. Lagoeiro (unpublished data), the fold-thrust system of the Chapada Diamantina was generated during two deformation phases in the course of the Brasiliano event: $i$ ) an older, ENEdirected contraction; and $i$ ) an younger, south verging thrusting.

Alkmim et al. (1993) postulated that the inversion of the aulacogen was caused by indentation of basement wedges on both the southern and northern terminations of the rift trough, as a consequence of the cratonward migration of the Brasiliano front.

Schobbenhaus (1996) recognized two superimposed rifts in the stratigraphic record of the northern Espinhaço range, the Espinhaço and Santo Onofre rifts, which developed, respectively, around $1.75 \mathrm{Ga}$ and $0.9 \mathrm{Ga}$, and underwent inversion after $650 \mathrm{Ma}$.

More recently, A. Danderfer $\mathrm{F}^{\circ}$ (unpublished data) demonstrated that the degree of inversion decreases dramatically towards the north, along the Paramirim corridor, so that to the north of town of Macaúbas (Fig. 2) the rift geometry remained almost fully preserved. Additionally, this author shows that the main inversion phase of the aulacogen was trig- 
gered by a general WSW-ENE-oriented shortening, and not by indentation of a basement wedge along the rift axis, as suggested by Alkmim et al. (1993).

\section{THE SOUTHERN PARAMIRIM CORRIDOR}

The area we choose for this study covers more than half of the southern Paramirim corridor and the external portion of the Rio Pardo salient of the Araçauí belt (Figs. 2 and 4). The results we obtained, along with data compiled from the literature, are shown in this and following sections.

Three distinct families of tectonic structures have been observed in the basement and the cover units along the southern Paramirim corridor:

- The oldest set of structures $\left(\mathrm{D}_{a}\right)$ consists of north-verging faults and folds that affect the basement, the Lagoa Real Complex and the sedimentary rocks of the Bebedouro and Salitre formations in the southwestern border of the Chapada Diamantina, and dominate the tectonic grain of the Rio Pardo salient. This set of fabric elements records the northward propagation of the Araçuaí belt deformation front.

- The second and dominant set of structures $\left(\mathrm{D}_{p}\right)$ is made up of a large variety of tectonic elements, including reverse, thrust and strike-slip faults in association with folds, ductile shear zones and various categories of small-scale structures, generated during the main episode of inversion of the Paramirim aulacogen in response to a WSW-ENE-oriented shortening.

- Normal faults, and normal reactivation of the preexistent contractional structures form the youngest set of tectonic elements $\left(\mathrm{D}_{e}\right)$ that records a post-inversion extension.

According to the nature and orientation of the dominant structures, the southern Paramirim corridor can be subdivided in two structural domains, I and II, separated by the Brumado-Caetité shear zone (Figs. 2 and 4).
STRUCTURAL Domain I

In structural domain I, located to the north of the Brumado-Caetité shear zone, the superimposed Espinhaço and Santo Onofre rift structures experienced increasing degrees of inversion towards the south (Moutinho da Costa and Inda 1982, A. Danderfer $\mathrm{F}^{\circ}$, unpublished data). To the north of the Brumado-Caetité shear zone, around $13^{\circ}$ of S latitude, the Paramirim aulacogen underwent full inversion, forming a basement-involved fold-thrust belt (Figs. 2, 4 and 5).

Along the northern Espinhaço range a deep half graben filled with Espinhaço Supergroup and Santo Onofre Group sediments is bounded to the west by the ENE-dipping Santo Onofre reverse fault (Figure 5, section B-B', Schobbenhaus 1996, Danderfer $\mathrm{F}^{\circ}$ and Dardenne 2002). The Santo Onofre fault brings Espinhaço strata on top of Santo Onofre Group sedimentary rocks, and also these units together on top of the basement, as shown on the crosssections of Figure 5. These relationships clearly indicate that the Santo Onofre fault is an inverted normal fault, that is, it was reactivated as reverse fault. On the east side of the range, a top-to-ENE fault zone progressively developed on the basementcover contact (A. Danderfer $\mathrm{F}^{\circ}$, unpublished data). As a whole, this fault zone has the shape of a propeller with dips varying between $25^{\circ}$ to WSW at $12^{\circ} \mathrm{S}$ Lat, vertical at $12^{\circ} 45^{\prime} \mathrm{S}$ Lat and $50^{\circ}$ to ENE, near the town of Macaúbas (Figs. 2, 4 and 5) (Costa and Inda 1982, A. Danderfer $\mathrm{F}^{\circ}$, unpublished data). In the vicinity of Macaúbas, almost the whole section of the graben fill is overturned (Schobbenhaus 1996, A. Danderfer $F^{\circ}$, unpublished data). Further south, this particular shear zone oscillates around the vertical position. When dipping WSW, the fault surface shows top-to-ENE kinematic indicators; when dipping ENE, hanging wall down to ENE indicators are observed. These relationships attest passive rotation of the fault surface during inversion.

Within the half graben of the northern Espinhaço range, Espinhaço and Santo Onofre strata are folded against the Santo Onofre fault. Large and 


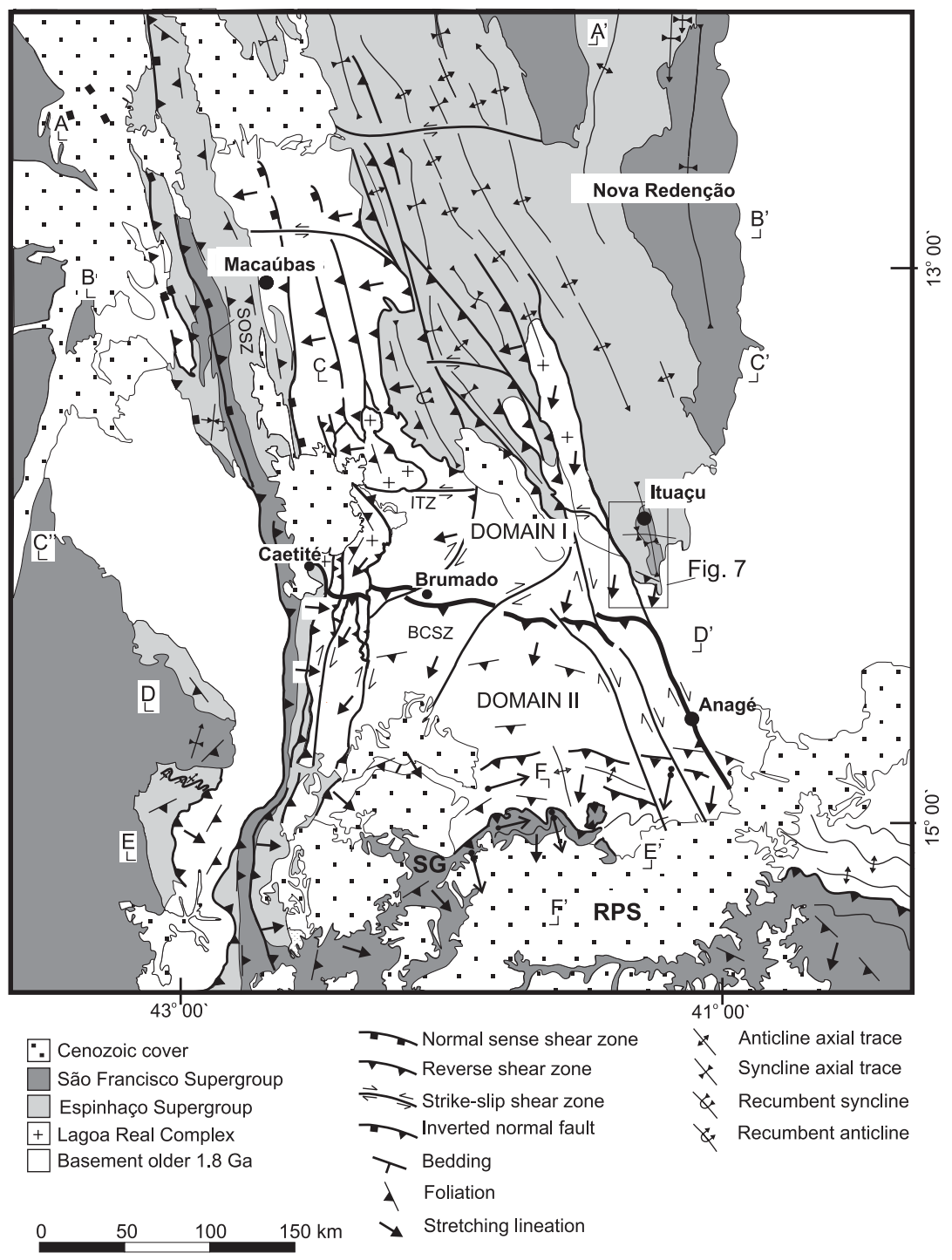

Fig. 4 - Geologic map of the study area, showing the distribution of main stratigraphic units and structures of the southern Paramirim corridor and Rio Pardo salient. Crosssections are provided by Figure 5. The box shows the location of Figure 8. (Based on Schobbenhaus et al. 1981, Barbosa and Dominguez 1996, A. Danderfer $F^{\circ}$, unpublished data). BCSZ - Brumado-Caetité shear zone, SOSZ - Santo Onofre shear zone, ITZ Itanajé transfer zone, RPI - Rio Pardo salient of the Araçuaí belt, SG - Serra Geral range.

open ENE-verging folds to the north pass gradually to smaller tight folds to the south, where an axial planar discontinuity progressively evolves to a slaty cleavage (A. Danderfer $\mathrm{F}^{\circ}$, unpublished data).

To the west of the Espinhaço range, besides other partially inverted half grabens, the carbonates of the Bambuí Group, lying unconformably on base- ment, become progressively involved in a narrow deformation zone, dominated by WSW-verging reverse faults and folds (Alkmim et al. 1996).

In the central portion of the corridor, basement rocks and gneisses of the Lagoa Real Complex are cut by a system of ductile-brittle shear zones. Striking NNW, these shear zones preferentially show 


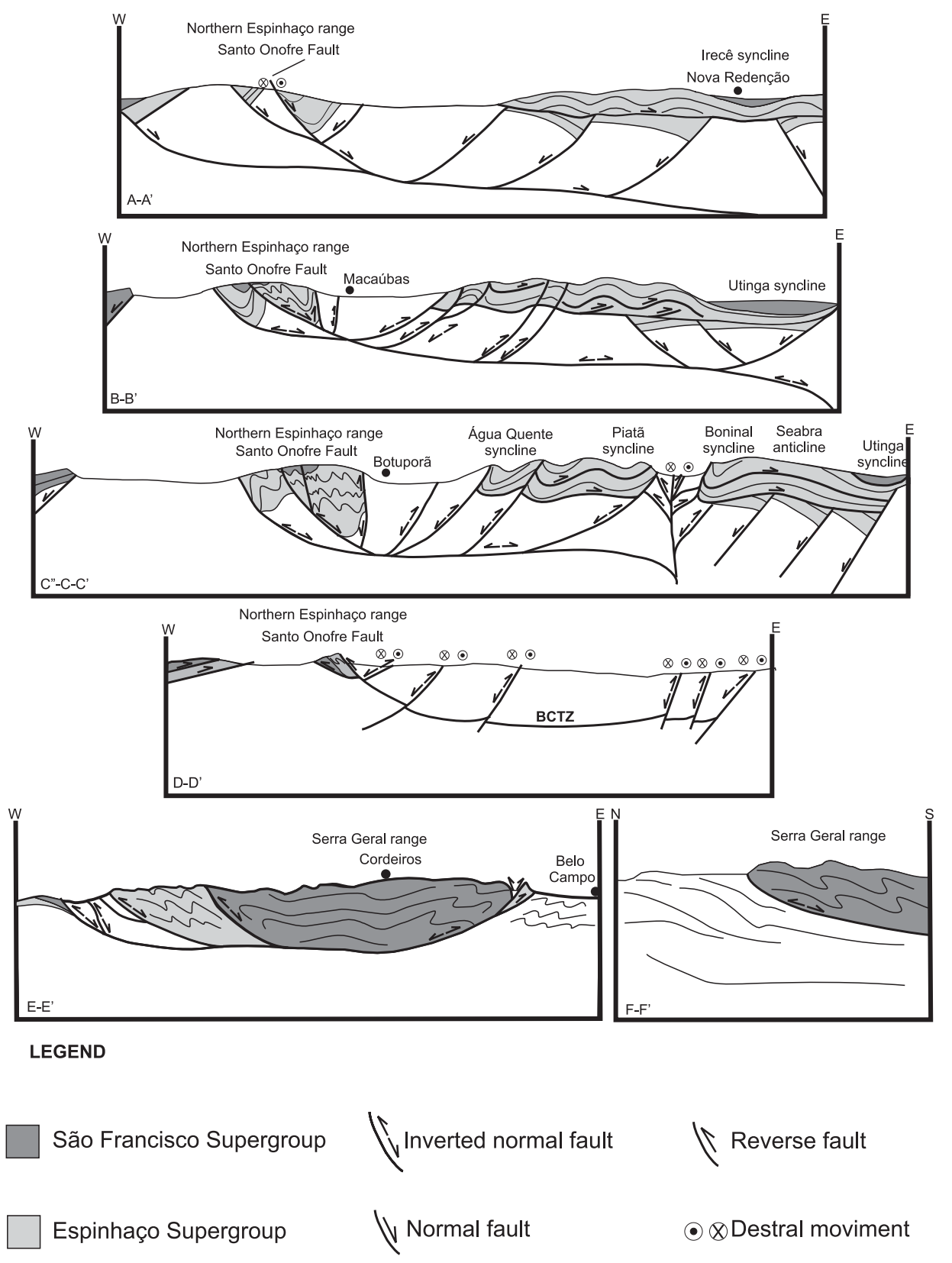

Fig. 5 - Cross-sections of the southern Paramirim corridor and Rio Pardo salient. The sections A-A' and B-B' incorporate modifications from sections by A. Danderfer $\mathrm{F}^{\circ}$ (unpublished data). BCSZ Brumado-Caetité shear zone.

top-to-ENE indicators. Stereonet plots of the mylonitic foliation and lineation of these zones are shown on Figure 6a,b.

The gneisses of the Lagoa Real Complex define a NS oriented stripe limited on both sides by reverse shear zones in this segment of the corridor (Figs. 2 and 4). The gneissic foliation has a maximum at 259/42, exhibiting a down-dip stretching lineation. This foliation is overprinted by a second generation of $\mathrm{D}_{p}$ folds, with hinges around 340/11 (Fig. 6c,d). Espinhaço and São Francisco Supergroup strata in the western Chapada Diamantina are folded and 


\section{Paramirim Corridor Domain I}
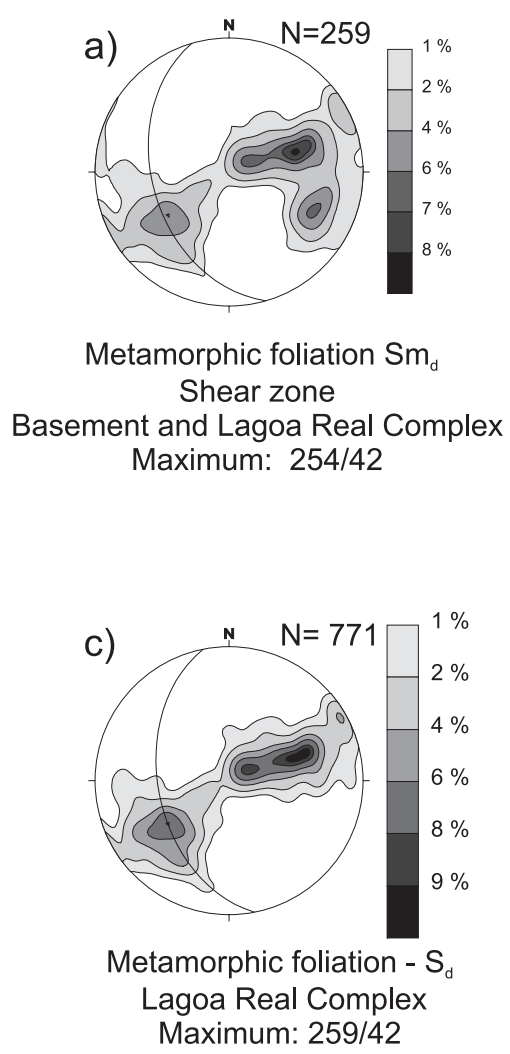

b)

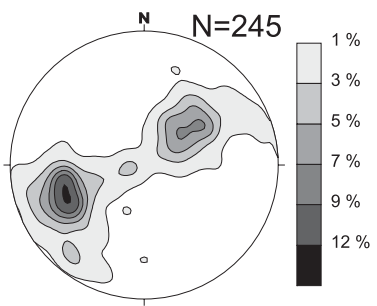

Stretching lineation - $\mathrm{Lxm}_{\mathrm{d}}$ Shear zone

Basement and Lagoa Real Complex Maximum: 250/37

d)

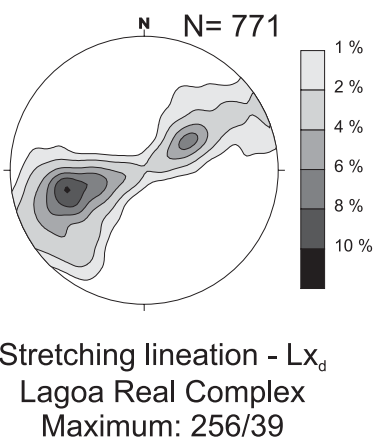

Fig. 6-Equal-area, lower hemisphere stereonet plots of poles to foliations and lineations of basement and Lagoa Real Complex in structural domain I.

thrust eastwards, forming, as mentioned, an embryonic basement-involved fold-thrust belt (A. Danderfer $\mathrm{F}^{\circ}$, unpublished data) (Figs. 2, 4 and 5, sections B-B' and C-C'). $\mathrm{D}_{p}$ deformation took place in two coaxial phases, a detached and a basement-involved phase (F.F. Alkmim and A. Danderfer $\mathrm{F}^{\circ}$, unpublished data). Detachments associated with folds trains, blind duplexes, and a large number of smallscale structures nucleated in the course of the first phase. Reverse and reverse-oblique faults cut the detachments afterwards, bring up basement slices and produce a second generation of ENE-verging folds.

In the keel of a relatively small syncline in the southern border of the Chapada Diamantina (Figs. 4 and 7), diamictites and carbonates, respectively, of the Bebedouro and Salitre formations, are affected by two generations of folds (B.B. Brito Neves and A.J. Pedreira, unpublished data), both associated with the development of cleavage. The older generation is E-W oriented and verges north. The younger set consists of large ENE-verging folds, related to the dominant $\mathrm{D}_{p}$ event. The older generation of folds is probably related to the propagation of the Araçuaí belt front northwards, in the same way that south directed folds and thrusts in the northern portion of the aulacogen represent deformation induced from the northern margin of the craton.

Nucleation of $\mathrm{D}_{p}$ fabric in this domain was associated with metamorphic reactions of greenschist 


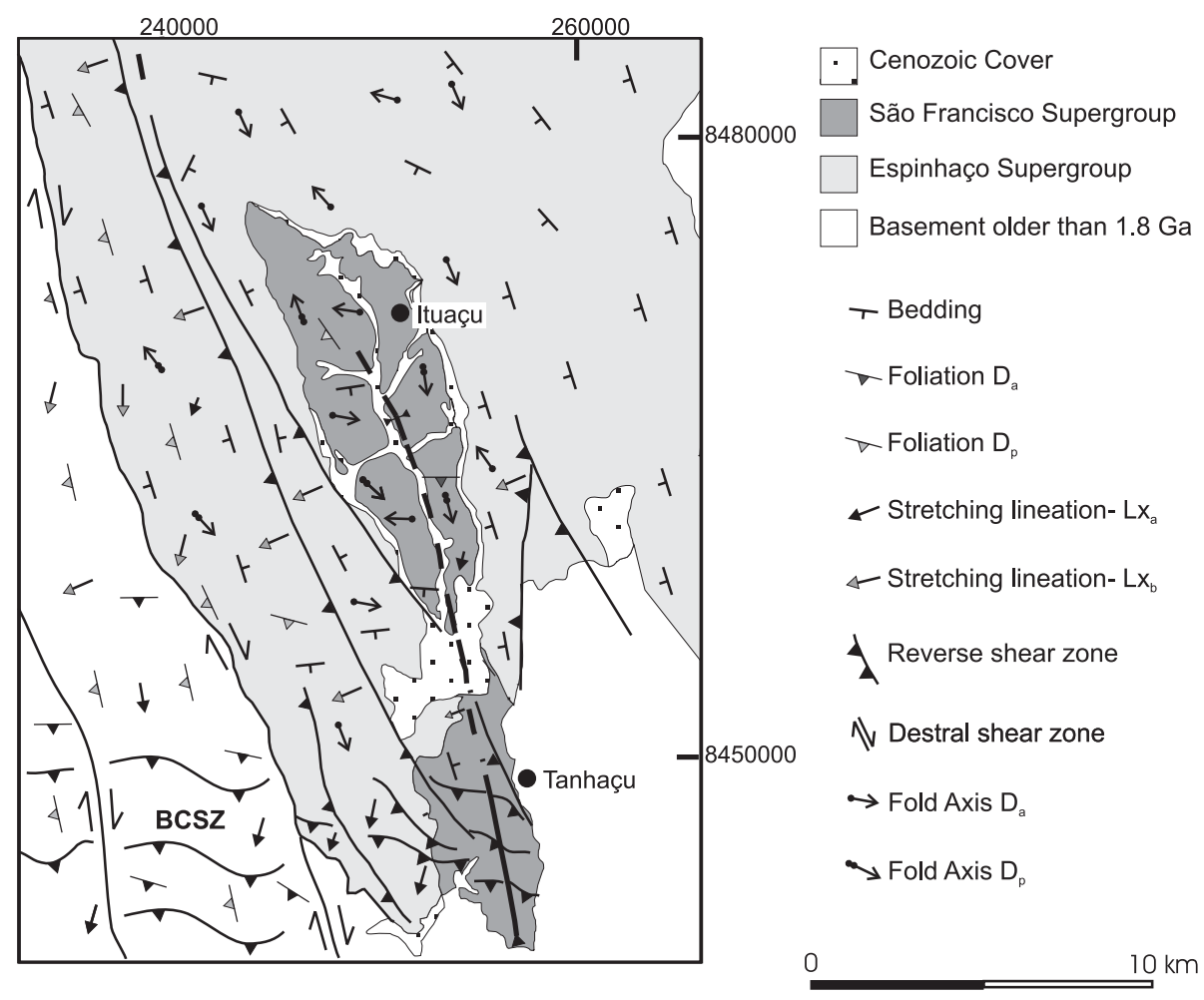

Fig. 7 - Simplified geologic map of the Ituaçu syncline region (Based on N.R. Menezes $\mathrm{F}^{\circ}$, unpublished data). BCSZ - Brumado Caetité shear zone.

facies, as attested by the mineral paragenesis quartz, white mica, kyanite, chloritoid, chlorite and albite in the metasedimentary and metavolcanic rocks of the Espinhaço Supergroup. Quartz c-axis fabric analysis carried out on $\mathrm{D}_{p}$ basement shear zones indicates preferential slip on the basal plane $<\mathrm{a}>$. Feldspars show brittle comminution and sericitization.

\section{The Brumado-Caetité Shear Zone}

The boundary between structural domains I and II is a 15 to $20 \mathrm{~km}$ wide s-shaped shear zone (Figs. 2 and 4). Near the town of Caetité (Figure 4), this shear zone corresponds to an arcuated thrust fault, with dips varying between $10^{\circ}$ and $40^{\circ}$ to $\mathrm{NE}$ and $\mathrm{E}$, respectively. Along the NNW-striking ramp the basement is brought on top of overturned strata of the Espinhaço Supergroup. To east of the town of Caetité the dip direction of the Brumado-Caetite shear zone changes gradually from north to south and then to southwest (Figs. 2 and 4). Dip values of the latter portion are shallow, varying between $10^{\circ}$ and $40^{\circ}$ (Fig. 8). The E-W-striking segment, cutting the basement and the Lagoa Real Complex, shows reverse to reverse-sinistral shear sense.

The Brumado-Caetité shear zone separates two domains of very distinct architecture and amount of strain. As shown in the previous section, in structural domain $\mathrm{I}$, inversion during the $\mathrm{D}_{p}$ event is accommodated along ENE-verging structures. On the other hand, strike to oblique-slip shear zones are the main manifestation of $\mathrm{D}_{p}$ along structural domain II, where the basement core is relatively less deformed. Furthermore, this shear zone might correspond to the inversion of a preexisting rift transfer, as pre-inversion geometries predicted for domains I and II are quite different.

As shown on the map of Figure 4 the BrumadoCaetité shear zone is offset by NS-oriented strikeslip faults, which represent the youngest components of the $\mathrm{D}_{p}$ set. As indicated by its top-to-north 


\section{Paramirim Corridor}

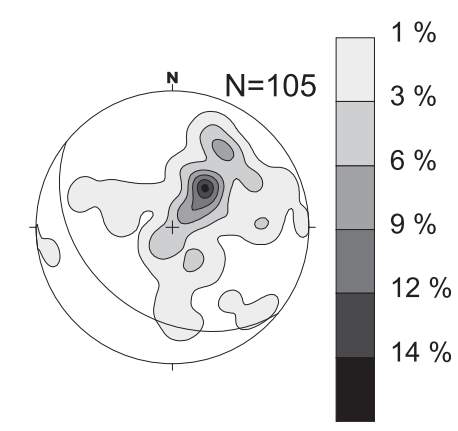

Brumado-Caetité shear zone Metamorphic foliation $-\mathrm{Sm}_{\mathrm{a}}$ Maximum: 220/30

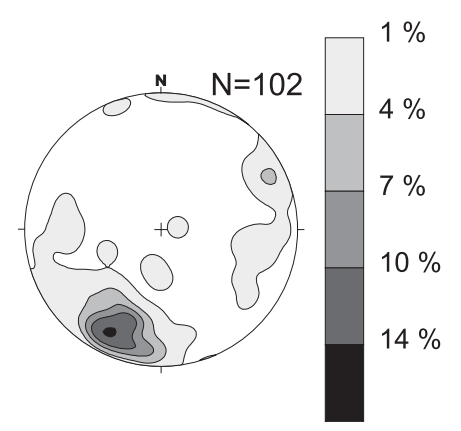

Brumado-Caetité shear zone Stretching lineation - Lxm Maximum:206/18

Fig. 8 - Equal-area, lower hemisphere stereonet plots of poles to foliations and lineations observed in the Brumado-Caetité shear zone.

sense of shear and cross-cut relationship with $\mathrm{D}_{p}$ and $\mathrm{D}_{e}$ the Brumado-Caetité shear zone nucleated during the $\mathrm{D}_{a}$ event.

\section{STRUCTURAL DOMAIN II}

The area to the south of the Brumado-Caetité transfer zone differs from the other segments of the corridor due to the fact that $\mathrm{D}_{p}$ shortening is differentially accommodated in the basement and cover units, regarding amount and form.

The western border of the corridor in the São Francisco basin is marked by E-dipping reverse faults, along which slices of basement covered by Espinhaço Supergoup strata were brought on top of São Francisco Supergroup sedimentary rocks (A.L. Bertholdo, unpublished data, Alkmim et al. 1996) (Figs. 2, 4 and 5).

The northern Espinhaço range comprises a narrow belt of strongly deformed Espinhaço Supergroup metasedimentary rocks, bounded by the Santo Onofre reverse fault to the west, and by a basement-involved thrust to the east (A.L. Bertholdo, unpublished data). The Santo Onofre fault continues further south, and keeping the same attributes, merges with the Araçuaí belt structures on the craton margin. The thrust on the east side of the range also merges with the Araçuaí belt to the south, dying out, however, in the Brumado-Caetité transfer zone to the north (Figs. 2, 4 and 5). Within the Espinhaço range belt, close and upright folds developed on the hanging wall of the Santo Onofre fault in domain I pass gradually to a WSW-verging train of large scale tight to isoclinal folds in domain II. In addition, a second generation of coaxial folds associated with a crenulation cleavage is observed along the whole belt. These younger folds are asymmetric and eastverging. Bedding, foliation and stretching lineation data collected in the deformed edge of the São Francisco basin and in the Espinhaço range are shown on Figure 9.

The basement core of the corridor displays a system of dextral strike-slip shear zones. Affecting in different ways both the basement and the Lagoa Real Complex, these shear zones show sinuous traces, striking between NE and NNW, and dipping $60^{\circ}$ to $90^{\circ}$ to $\mathrm{W}$ (Figure 10a,b). The attitudes of the main foliation and stretching lineation within these shear zones are 260/18 e 219/14, respectively (Figure 10a,b). The gneisses of the Lagoa Real Complex are pervasively deformed, and their fabric elements reproduce those found along discrete shear zones in the basement. Attitudes of the 

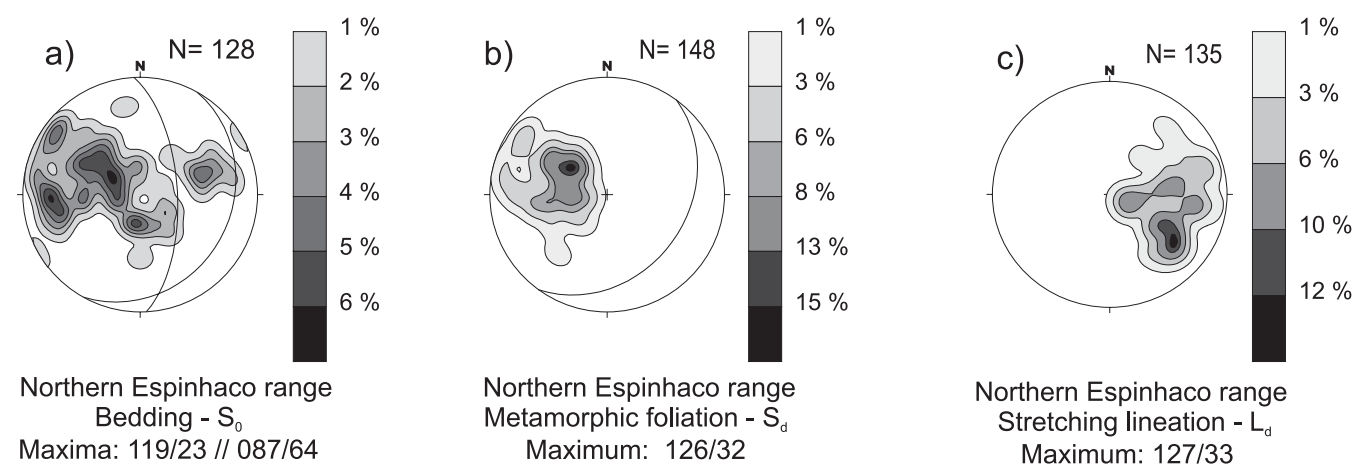

Fig. 9 - Equal-area, lower hemisphere stereonet plots of poles to foliations and lineations observed in the São Francisco basin and northern Espinhaço range, structural domain II.

dominant foliation and stretching lineation in the Lagoa Real Complex are 254/45 and 219/14, respectively, recording a preferential dextral motion (Figure 10c,d). These shear zones nucleated during a late phase of $\mathrm{D}_{p}$ event, as they cut all previously described structures, including the Brumado-Caetité transfer zone. Some of them represent reactivation of reverse faults, which in turn correspond to inverted rift normal faults.

A series of discrete and shallow-dipping shear zones progressively obliterates the ancient basement fabric near the southern boundary of domain II. These shear zones, also cut by the of dextral shear zone system, evolve to the dominant fabric of the outer arc of the Araçuaí belt salient, as described in the next section.

Except for the late stage dextral shear zone system, development of $\mathrm{D}_{p}$ structures in domain II is associated with metamorphic reactions in amphibolite facies conditions. The syn-kinematic paragenesis of the Lagoa Real Complex includes epidote, albite, garnet (andradite - grossuralite), hedenbergite, diopside, quartz, biotite and hastingsite. Along the eastern escarpment of the Espinhaço range, the metamorphic paragenesis of the cover units includes almandine, staurolite, kyanite, quartz, and biotite, which indicates metamorphic temperatures between $550^{\circ}$ and $670^{\circ} \mathrm{C}$ and pressures in the range of 4 to 12 kbar (Bucher and Frey 1994). Alkali feldspar and plagioclase grains underwent strong recrystal- lization through subgrain rotation, forming a polygonal texture. Quartz c-axes fabrics show preferred orientations at a high angle to the foliation plane and parallel to the Y direction.

The metamorphic paragenesis observed in the late stage dextral shear zones, consisting of white mica, quartz and chlorite, is typical of the greenschist facies. Feldspar crystals experienced brittle fracturing and sericitization, whereas quartz grains show evidences of ductile behavior. Quartz c-axis fabrics are asymmetric with preferred orientations at high angles to the foliation plane.

\section{THE RIO PARDO SALIENT}

In part due to the lack of exposure, the Rio Pardo salient is one of the less studied segments of the Araçuaí belt. Almeida et al. (1978) presented a comprehensive synthesis on the stratigraphy, tectonic framework and metamorphic zoning of the northern segment of the Araçuai belt, covering much of the Rio Pardo salient area. During our field work we investigated the basement exposures located along the craton boundary and outcrops of the cover units along the ca. $150 \mathrm{~km}$ of the Serra Geral, the morphological expression of the salient.

\section{STRATIGRAPHY}

The basement of the Araçuaí belt in the study area consists of 3.4 to 3.2 Ga old orthogneisses of tonalitic, granodioritic and granitic composition, locally 


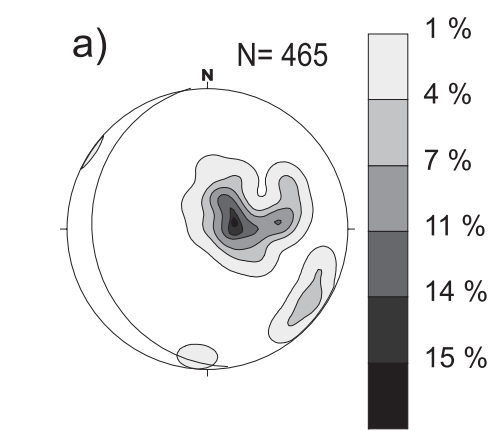

Metamorphic foliation- $\mathrm{Sm}_{\mathrm{d}}$ Shear zones Basement and Lagoa Real Complex Maximum: 260/18

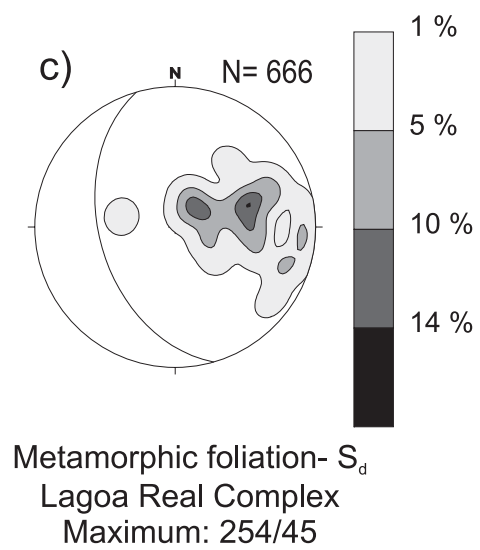

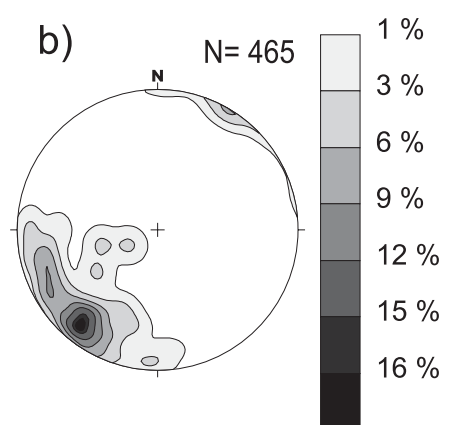

Stretching lineation - Lxm Shear zones Basement and Lagoa Real Complex Maximum: 086/66

Fig. 10 - Equal-area, lower hemisphere stereonet plots of poles to foliations and lineations for the shear zones affecting the basement and Lagoa Real Complex in structural domain II.

showing variable degrees of migmatization (Martin et al. 1991, Nutman and Cordani 1993, Bastos Leal et al. 1998, 2000).

The supracrustal units of the Rio Pardo salient are metasandstones interbedded with pelites and subordinate conglomerates, covered by diamictites and turbiditic schists. The basal metasandstone were correlated to the Espinhaço Supergroup by Almeida et al. (1978), Inda and Barbosa (1978), Barbosa and Dominguez (1996). Pedrosa Soares et al. (2001) and Lima et al. (2002) on the other hand correlated the whole metasedimentary package exposed along the salient to the Ribeirão da Folha Formation of the Macaúbas Group.

\section{TECTONIC FRAMEWORK}

As previously mentioned, close to the craton boundary, Archean TTG's gneisses of the basement are cut by a series of discrete, shallow, south-dipping shear zones. Further south these shear zones pervasively affect the basement rocks, forming a southdipping detachment at the base of the metasedimentary package involved in the Araçuaí belt. The ca. $200 \mathrm{~m}$ thick detachment zone follows the curved trace of the belt, dipping $10-25^{\circ}$ to SE and $25^{\circ}$ to $\mathrm{S}$ in the western and eastern portions of the salient, respectively (Figure 11a,b). Orientation of the stretching lineation on the detachment surface varies be- 
tween 130/20,170/15 and 190/12. Kinematic indicators on this surface attest to an overall N-NWdirected motion.

As already noticed by Almeida et al. (1978), above the detachment, the metasedimentary rocks of the Macaúbas Group are folded around two almost orthogonal axes, thereby creating local domeand-basin interference patterns. The older generation of folds is north-verging and associated with north directed thrusts. The attitude of the axial plane foliation is 209/14, whereas the stretching lineation shows preferred orientations at 203/14 (Figure $11 \mathrm{c}, \mathrm{d})$. Along the whole length of the Rio Pardo salient, both the detachment and the north-verging $\mathrm{D}_{a}$ structures are folded around axes oriented at $190 / 12$, and offset by the southern termination of the dextral shear zone system $\left(\mathrm{D}_{p}\right)$ that dominates the basement core of the southern Paramirim corridor. The sinuous structural traces of the salient that stands out in maps and images of the region result from the superimposition of $\mathrm{D}_{p}$ and $\mathrm{D}_{a}$ strutures.

An amphibolite facies metamorphism (Almeida et al. 1978) was associated with the development of $\mathrm{D}_{a}$ north-verging structures in the salient, as attested by the occurrence of staurolite, garnet, and biotite in the pelitic schists of the Macaúbas Group.

\section{TECTONIC INTERACTION BETWEEN THE PARAMIRIM AULACOGEN AND THE ARAÇUAÍ BELT: A MODEL}

The results of our structural analysis presented in the previous sections, along with data obtained from the literature, can be summarized as follows:

1. The Paramirim corridor, as the main deformation zone of the Paramirim aulacogen, coincides with the original rift axis and comprises two segments of distinct geologic architecture. The northern segment preserves the original rift structures (A. Danderfer $\mathrm{F}^{\circ}$, unpublished data) and also contains the interference zone with the marginal Rio Preto belt near the craton boundary. The southern segment displays increasing metamorphic grade and degrees of inversion towards the south and interacts with the Rio Pardo salient of the Araçuaí belt on the craton margin.

2. Three generations of tectonic structures were recognized in the basement and cover units of the study area. The oldest generation $\left(\mathrm{D}_{a}\right)$ reflects north directed tectonic transport, recording the development of the Rio Pardo salient of the Araçuaí belt. The second generation $\left(D_{p}\right)$ comprises the most prominent structures of the southern Paramirim corridor and the aulacogen as a whole. $\mathrm{D}_{p}$ structures result from a general WSW-ENE shortening, responsible for the main inversion phase of the aulacogen. The youngest set of tectonic elements $\left(\mathrm{D}_{e}\right)$ nucleated during an extensional reactivation of the preexistent structures, and probably represents post-orogenic extension.

3. Crosscutting relationships among the fabric elements of the Paramirim corridor and the Araçuaí belt clearly indicate that the development of the Rio Pardo salient predates the main inversion phase of the Paramirim aulacogen.

Based on these results and on the geochronological data provided Celino et al. (2000), Nalini Jr et al. (2000), Noce et al. (2000), Pedrosa Soares and Wiedemann Leonardos (2000), Pedrosa Soares et al. (1992, 2001), Tack et al. (2001) and Silva et al. (2002), we propose an evolutionary model for the development of the Paramirim aulacogen and its tectonic interaction with the Araçuaí belt during the inversion processes. This model comprises the following stages illustrated by the cartoon shown on Figure 12:

Stage I: In the Tonian period, at ca. $850 \mathrm{Ma}$, the Macaúbas rift system generated on the São Francisco/Congo continent reaches its full development. At that time, the Macaúbas rift system was made up by a Red Sea-type ocean, connected to an ensialic rift arm, which corresponds to the presentday Paramirim aulacogen. Turbidites of the Santo Onofre Group were filling the halfgraben of the 


\section{Rio Pardo salient}
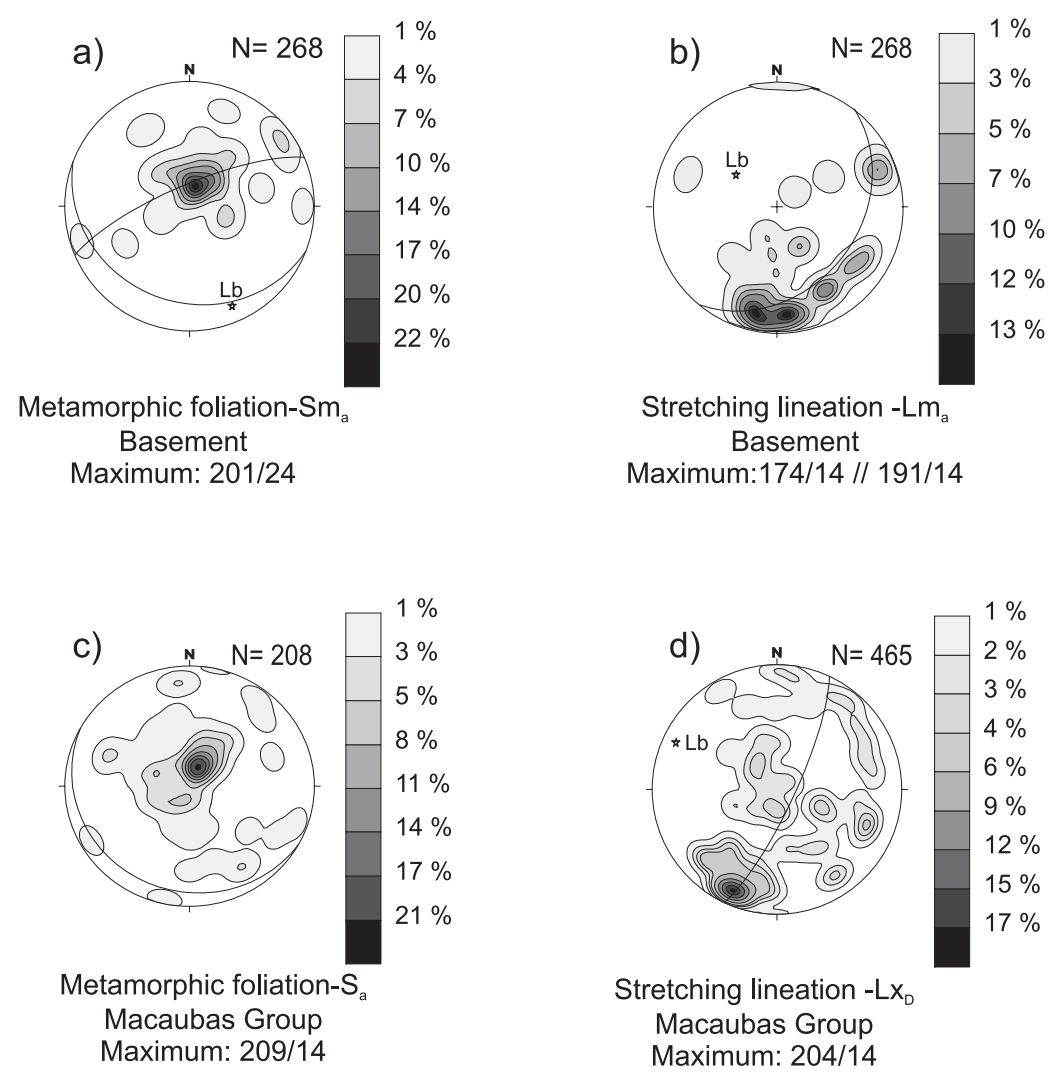

Fig. 11 - Equal-area, lower hemisphere stereonet plots of poles to foliations and lineations of the Rio Pardo salient of the Araçuaí belt.

northern Espinhaço range (A. Danderfer $\mathrm{F}^{\circ}$, unpublished data). In this context, the present-day Rio Pardo salient of the Araçuaí belt formed in the area of junction between the ensialic rift and the passive margins of the Macaúbas system.

Stage II: Probably by the end of the Neoproterozoic III, around $580 \mathrm{Ma}$, the Macaúbas ocean started to close, giving rise to the generation of the Araçuaí orogen. During an early phase of the closure, northward propagation of the orogenic front inverted the junction between the aulacogen and the passive margins, thereby initiating the Rio Pardo salient and inducing inversion in the southern portion of the aulacogen trough.
Stage III: Immediately after the first stage of closure, basin inversion affects almost the whole Macaúbas rift system in response to a general WSWENE shortening. The Paramirim aulacogen experienced progressive inversion and metamorphism towards the south and the Araçuaí orogen formed.

Stage IV: In a similar way as in the Araçuaí orogen around $500 \mathrm{Ma}$, a post-inversion extension reactivated the preexisting structures in variable degrees.

\section{DISCUSSION}

According to the model presented here, the inversion of the Paramirim aulacogen took place during the Brasiliano event in the Late Neoproterozoic or, 

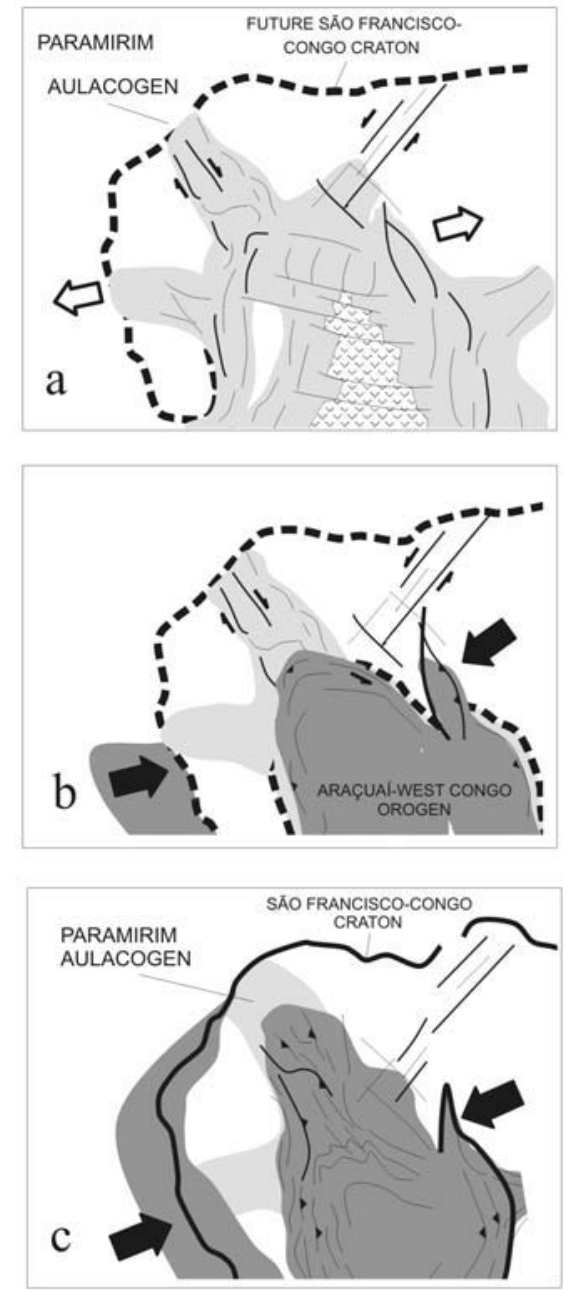

AREAS AFFECTED BY THE BRASILIANO DEFORMATION

MACAÜBAS RIFT SYSTEM OCEANIC CRUST

Fig. 12 - Cartoon illustrating a model for the tectonic evolution of the Paramirim aulacogen and its interaction with the Araçuaí belt.

possibly, in the Cambrian. Although we do not provide any geochronological data, this assumption is supported by the following facts: $i$ ) both the first and second generations of inversion structures $\left(\mathrm{D}_{a}\right.$ and $\mathrm{D}_{p}$ ) affect carbonates of Bambuí Group and the Salitre Formation, the youngest Neoproterozoic (probably Cryogenian) cover units of the aulacogen; ii) structures of the main stage of inversion (Dp) clearly overprint the dominant features of the Rio Pardo salient of the Araçuaí belt on the craton margin.

Various authors had already suggested a Neoproterozoic Brasiliano age for the inversion of the Paramirim aulacogen (e.g.: Caby and Arthaud 1987, Alkmim et al. 1993, 1996, Schobbenhaus 1996, A. Danderfer $\mathrm{F}^{\circ}$, unpublished data). A Neoproterozoic age for the inversion of the aulacogen has an implication on the São Francisco craton concept. However, as shown in previous sections, the central portion of the aulacogen that includes much of the northern half of the Paramirim corridor, did not experience inversion. Thus, we consider that the São Francisco craton concept is still valid, although the location of its limits, specially those located in the interference zone between the Paramirim aulacogen and the marginal belts, demands revision. We suggest that the trace of the limit should be modified in such a way that the whole segment of the Paramrim corridor to the south of $13^{\circ} \mathrm{S}$ Latitude remains outside the craton.

In our model we postulate that the main inversion phase $\left(\mathrm{D}_{p}\right)$ resulted from a WSW-ESE compressional field, as previously suggested by A. Danderfer $\mathrm{F}^{\circ}$ (unpublished data). Thus, the indentation model proposed by Alkmim et al (1993) is valid only for the $\mathrm{D}_{a}$ event. The $\mathrm{D}_{a}$ event, as associated with the development and propagation of the Rio Pardo salient further into the aulacogen trough, at first glance does not seem to reflect the WSWENE oriented compression, suggesting the action of an independent event. From a regional perspective, however, this incompatibility appears to be only apparent.

According to the tectonic scenario of the São Francisco craton region at the time of the closure of the Macaúbas rift system, the $\mathrm{D}_{p}$ event must be induced by the collisions in which the São Francisco plate was involved at the end of the Neoproterozoic. Inversion of intracratonic rift structures at long distances from the plate margins is a phenomenon documented in various continents (see, for example, Marshak et al. 2000 and references therein).

But how does the inversion of the Paramirim 
aulacogen work together with the generation of the Araçuaí-West Congo orogen? Following the models by Brito Neves et al. (1999), Campos Neto (2000) and Alkmim et al. (2001), we suggest that the closure of the Macaúbas rift system, including the Red Sea-type ocean, precursor of the AraçuaíWest Congo orogen, was induced by the interactions between the São Francisco/Congo, Amazonia, Rio de la Plata and other plates. As the São Francisco peninsula moves against the Congo continent, triggering the initial closure of the system, the first motions would be associated to a very high degree of strain partitioning. In this scenario it seems to be very likely that the Rio Pardo salient developed during an early stage of the orogen generation, and later shortened as the closure progressed and incorporated pericratonic and cratonic domains.

\section{CONCLUSIONS}

The Paramirim aulacogen, developed in the course of two stages of rifting in the northern São Francisco craton, experienced intensive processes of inversion, so that the original rift fabric remained only preserved in a relatively small area of its central portion. During the inversion process, the southern Paramirim aulacogen interacted with the orthogonally oriented Rio Pardo salient of the Araçuaí belt that bounds the São Francisco craton to the southeast.

Three families of fabric elements were discriminated among the various compressional structures that affect the Neoproterozoic sedimentary rocks of São Francisco Supergroup in the southern sector of the aulacogen and along the Rio Pardo salient.

The older generation of tectonic elements includes north verging thrusts and folds in the metasedimentary units, connected to a basal detachment located along the basement/cover contact. These structures affect the Salitre Carbonates in the southern border of the Chapada Diamantina and dominate the tectonic picture of the Rio Pardo salient along the Serra Geral. They were formed during an early stage of the closure of the Macaúbas rift system as a con- sequence of the propagation of the Araçuaí belt front into the craton interior, channeled by the weak zone represented by the deepest portions of the aulacogen.

The second event causes frontal inversion of the Paramirim aulacogen and intensive folding around NNW-oriented axes in the Rio Pardo salient. Two miniature basement involved fold-thrust belts of opposite vergence formed in the southern portion of the aulacogen, reflecting advanced closure of the Macaúbas rift system under an overall WSW-ENEoriented shortening direction related to the generation of the Araçuaí-West Congo orogen.

In sum, we conclude that, the development of the Araçuaí belt and the inversion of the Paramirim intracratonic rift during the Brasiliano event resulted from the same process, namely the closure of the Macaúbas rift system due to collisions involving the São Francisco/Congo plate in the course of the assembly of West Gondwana.

\section{ACKNOWLEDGMENTS}

This work was financed by Conselho Nacional de Desenvolvimento Científico e Tecnológico (CNPq), Project $n^{\circ} 46.4451 / 00-0$. The authors are grateful for the support received from the Companhia Baiana de Pesquisa Mineral (CBPM), Indústrias Nucleares do Brasil (INB) and Companhia de Pesquisa de Recursos Minerais (CPRM) during the field work. Simone C.P. Cruz benefited from a CNPq doctoral fellowship, grant $n^{\circ} 140739 / 2000-9$. CNPq also provides a research grant $\left(\mathrm{n}^{\circ} 300833 / 99-7\right)$ to F.F. Alkmim. This paper greatly benefited from the constructive criticism of two anonymous reviewers.

\section{RESUMO}

O aulacógeno do Paramirim, instalado na porção norte do Cráton do São Francisco, corresponde a dois riftes superpostos e parcialmente invertidos de idades paleo e neoproterozóicas. A Saliência do Rio Pardo da Faixa Araçuaí define o limite local do cráton e interfere com as estruturas do aulacógeno. Visando determinar o mecanismo e a idade da interação tectônica entre essas feições durante o 
processo de inversão, uma análise estrutural foi realizada na porção meridional do aulacógeno do Paramirim e ao longo da Saliência do Rio Pardo. Os resultados obtidos indicam que a Saliência do Rio Pardo formou-se durante um estágio precoce de fechamento do sistema de riftes neoproterozóicos Macaúbas e refletindo o início do desenvolvimento do Orógeno Araçuaí. O front orogênico propagou-se em direção a norte, Cráton adentro, causando um primeiro estágio de inversão da terminação sudeste da calha aulacogênica. Posteriormente, o Aulacógeno do Paramirim experimentou o principal estágio de inversão, o qual levou ao desenvolvimento de um sistema de dobramentos e cavalgamentos com embasamento envolvido e orientado na direção NNW. Esses elementos tectônicos se superimpõem à Saliência do Rio Pardo e estruturas de ambos estágios de inversão afetam a Formação Salitre, a mais jovem unidade neoproterozóica da área, indicando assim uma idade no máximo tardi-neoproterozóica para todos os estágios de inversão do aulacógeno do Paramirim.

Palavras-chave: Orógeno Araçuaí-Oeste Congo, Faixa Araçuaí, aulacógeno do Paramirim, evento Brasiliano.

\section{REFERENCES}

Alkmim FF And Martins Neto M. 2001. A Bacia intracratônica do São Francisco: Arcabouço estrutural e cenários evolutivos. In: PINTO CP AND Martins Neto MA (Eds), Bacia do São Francisco. Geologia e Recursos Naturais. SBG/MG, Belo Horizonte, MG, Brasil, p. 9-30.

Alkmim FF, Brito Neves BB And Alves JAC. 1993. Arcabouço tectônico do Cráton do São Francisco - uma revisão. In: DOMINGUEZ JM AND Misi A (Eds), O Cráton do São Francisco, Salvador: SBG/NBA-SE, p. 45-62.

Alkmim FF, Chemale Jr F And Endo I. 1996. A deformação das coberturas proterozóicas do Cráton do São Francisco. Rev Esc Minas 1: 22-38.

Alkmim FF, Marshak S And FOnseCA MA. 2001. Assembling West Gondwana in the Neoproterzoic: Clues from the São Francisco craton region, Brazil. Geology 29: 319-322.

Almeida FF. 1977. O Cráton do São Francisco. Rev Bras Geocienc 4: 349-364.

Almeida FFM, Hassui Y, Rodrigues EP AND
Yамамото JK. 1978. A Faixa de dobramentos Araçuaí na região do Rio Pardo. In: Congresso Brasileiro de Geologia, 30, Recife, PE, Brasil, SBG 1: 270-283.

BARBOSA JSF. 1990. The granulites of the Jequié Complex and Atlantic Mobile Belt, Southern Bahia, Brazil - An expression of Archean Paleoproterozoic Plate Convergence. In: Vielzeuf D ANd Vidal PH (Eds), Granulites and Crustal Evolution. Springer Verlag, Clermont Ferrand, France, p. 195-221.

BARbos A JSF And Dominguez JML. 1996. Mapa Geológico do Estado da Bahia. Escala: 1.000.000. Texto explicativo, Salvador, SGM, 382 p.

Barbos A JSF And Fonteilles M. 1993. Síntese sobre o metamorfismo da região granulítica do sul da Bahia. Rev Bras Geocienc 21: 1-13.

BARbosa JSF AND SABATÉ P. 2002. Geological feature and the paleoproterozoic of four archean crustal segments of the São Francisco craton, Bahia, Brazil: A syntesis. An Acad Bras Cienc 2: 343-359.

Bastos leal LR, Teixeira W, Cunha JC AND MACAMBIRA MJB. 1998. Archean tonalitictrondhjemitic and granitic plutonism in the Gavião block, São Francisco craton, Bahia, Brazil: Geochemical and geochronology characteristics. Rev Bras Geocienc 2: 209-220.

Bastos leal LR, Teixeira W, Cunha JC, Leal ABM, MACAMBIRA MJB And Rosa MLS. 2000. Isotopic signatures of paleoproterozoic granitoids of the Gavião block and implications for the evolution of the São Francisco craton, Bahia, Brazil. Rev Bras Geocienc 1: 66-69.

Brito Neves BB, SÁ JM, Nilson AA And BoteLHO NF. 1996. A tafrogênese estateriana nos blocos paleoproterozoicos da América do Sul. Geonomos 3: $1-21$.

Brito Neves BB, Campos Neto MC and Fuck RA. 1999. From Rodinia to Western Gondwana: An approach to the Brasiliano-Pan African cycle and orogenic collage. Episodes 22: 155-199.

Bucher K And Frey M. 1994. Petrogenesis of Metamorphic Rocks. Springer-Verlag, Germany, 307 p.

CABy R And ARThaud M. 1987. Petrostructural evolution of the Lagoa Real subalcaline metaplutonic complex (Bahia, Brasil). Rev Bras Geocienc 4: 636.

Campos Neto MC. 2000. Orogenic systems from 
Southwestern Gondwana. An approach to Brasiliano-Panafrican Cycle and Orogenic Collage in Southeastern Brazil. In: CoRdani UG, Milani EJ, Thomaz $\mathrm{F}^{\circ}$ A And CAmpos DA (Eds), Tectonic Evolution of South America, Rio de Janeiro: SBG, p. 335-365.

Celino JJ, Botelho NF And Pimentel MM. 2000. Genesis of neoproterozoic granitoid magmatism in the eastern Araçuaí fold belt, eastern Brazil: Field, geochemical and $\mathrm{Sr}-\mathrm{Nd}$ isotopic evidence. Rev Bras Geocienc 1: 135-139.

Cordani UG, Sato K And Marinho MM. 1985. The geologic evolution of the ancient granite-greenstone terrane of central-southern Bahia, Brazil. Precamb Res 27: 187-213.

Cordani UG, Iyer SS, TAYlor PN, Kawashita K, SATO K AND McReath I. 1992. Pb-Pb, Rb-Sr, and $\mathrm{K}-\mathrm{Ar}$ sistematic of the Lagoa Real uranium province (south-central Bahia, Brazil) and the Espinhaço Cycle (ca. 1.5-1.0 Ga). J South Amer Earth Sci 1: 33-46.

Costa LAM AND IndA HAV. 1982. O Aulacógeno do Espinhaço. Cienc Terra 2: 13-18.

Costa PHO, Andrade ARF, LOpes GAC And SouzA SL. 1985. Projeto Lagoa Real - Mapeamento Geológico 1:25.000. CBPM/NUCLEBRAS/ SME 1: 455.

DANDERFER $\mathrm{F}^{\circ}$ A AND DARDEnNe MA. 2002. Tectonoestratigrafia da bacia Espinhaço na porção centronorte do Cráton do São Francisco: registro de uma evolução poliistórica descontínua. Rev Bras Geocienc 4: 449-460.

Dominguez JML. 1993. As coberturas do Cráton do São Francisco: Uma abordagem do ponto de vista da análise de bacias. In: Dominguez JML AND BARbosa JSF (Eds), O Cráton do São Francisco, Salvador: SBG/NBA-SE, p. 137-155.

DomingueZ J ML. 1996. As coberturas plataformais do Proterozóico Médio e Superior. In: BARBos A JSF And Dominguez JML (Eds), Mapa Geológico do Estado da Bahia, Texto Explicativo, Salvador: SGM, p. 109-112.

DUSSIN IA AND DUSSIN TM. 1995. O Supergrupo Espinhaço: Modelo de evolução geodinâmica. Geonomos 1: 19-26.
FigUeIREDO MCH. 1989. Geochemical evolution of eastern Bahia, Brazil: A probably early-proterozoic subduction-related magmatic arc. J South Amer Earth Sci 2: 131-145.

Figueiredo MCH And Barbosa JSF. 1993. Terrenos metamórficos de alto grau do Cráton do São Francisco. In: Dominguez JML AND Misi A (Eds), O Cráton do São Francisco, Salvador: SBG/ NBA-SE, p. 63-84.

INDA HAV AND BARBOSA JF. 1978. Texto Explicativo para o Mapa Geológico do Estado da Bahia. Salvador, BA, Brasil, SME/COM, 137 p.

Lima SaA, Matins Neto MA, Pedrosa Soares AC, Cordani UG and Nutman A. 2002. A Formação Salinas na área-tipo, NE de Minas Gerais: Uma proposta de revisão da estratigrafia da Faixa Araçuaí com base em evidências sedimentares, metamórficas e idades U-Pb SHRIMP. Rev Bras Geocienc 32: 491-500.

Lobato LM And Fyfe W. 1990. Metamorphism and mineralization at Lagoa Real, Bahia. Econom Geol 85: 968-989.

Macedo MH And Bonhomme MG. 1984. Contribuição à cronoestratigrafia das Formações Caboclo, Bebedouro e Salitre na Chapada Diamantina (BA) pelos métodos RB-Sr e K-Ar. Rev Bras Geocienc 3: 153-163.

Marshak S, Karlstrom K And Timmons JM. 2000. Inversion of Proterozoic extensional faults: An explanation for the pattern of Laramide and ancestral Rockies intracratonic deformation, United States: Geology 28: 735-738.

Martin H, Peucat JJ, Sabaté P and Cunha JC. 1991. Un segment de croûte continentale d'age archéean ancien (3.5 millards d'années): lê massif de Sete Voltas (Bahia, Brésil). Acad Sci Phis 313: 531-538.

Martins Neto M And Alkmim FF. 2001. Estratigrafia e evolução tectônica das bacias neoproterozóicas do paleocontinente São Francisco e suas margens: registro da quebra de Rodínia e colagem de Gondwana. In: Pinto CP And Martins Neto M (Eds), A Bacia do São Francisco: Geologia e Recursos Naturais, SBG/MG, p. 9-30.

Maruèjol P, Cuney M, Fuzikawa K, Mario Netto A And Poty B. 1987. The Lagoa Real 
subalkaline granitic complex (South Bahia, Brazil): A source for uraniun mineralizations associated with Na-Ca metassomatism. Rev Bras Geocienc 4: 578-594.

Mascarenhas JF And GARCia TM. 1989. Mapa Geocronológico do Estado da Bahia. SME, Texto Explicativo. Salvador, BA, Brasil, 130 p.

Misi A. 2001. Estratigrafia isotópica das seqüências do Supergrupo São Francisco, coberturas neoproterozóicas do Cráton do São Francisco: idade e correlações. In: PINTO CP AND MARTins Neto MA (Eds), Bacia do São Francisco: Geologia e Recursos Minerais, Minas Gerais: SBG-MG, p. 67-92

Moutinho da Costa LA And Inda HAV. 1982. O Aulacógeno do Espinhaço. Cienc Terra 2: 13-18.

Nalini JR HA, Bilal E And Correia Neves JM. 2000. Syn-collisional peraluminous magmatism in the Rio Doce region: Mineralogy, geochemistry and isotopic data of the neoproterozoic urucum suite (eastern Minas Gerais State, Brazil). Rev Bras Geocienc 1: 120-125.

Noce CM, Macambira MJB and Pedrosa SoARES AC. 2000. Chronology of neoproterozoiccambrian granitic magmatism in the Araçuaí Belt, eastern Brazil, based on single zircon evaporation dating. Rev Bras Geocienc 1: 25-29.

NUTMAN AP AND CORDANI UG. 1993. SHRIMPU-Pb zircon geochronology of Archean granitoids from the Contendas Mirante area of the São Francisco Craton, Bahia, Brazil. J South Amer Earth Sci 7: 107-114.

Pedrosa Soares AC and Wiedemann LeonarDOS C. 2000. Evolution of the Araçuaí belt and its connection to the Ribeira belt, eastern Brazil. In: Cordani UG, Milani EJ, Thomaz FA and CAmpos DA (Eds), Tectonic Evolution of South America, Rio de Janeiro: SBG, p. 265-185.

Pedrosa Soares AC, Noce CM, Vidal PH, Monteiro RLBP ANd LeOnARdos OH. 1992. Toward a new model for the Late Proterozoic Araçuaí (SE Brazil) - West Congolian (SW Africa) Belt. J South Amer Earth Sci 1/ 2: 22-47.

Pedrosa Soares AC, Vidal P, LeOnardos OH AND BRito Neves BB. 1998. Late Proterozoic oceanic remnants in eastern Brazil: Further refutation of an exclusively ensialic evolution for the Araçuaí-West Congo orogen. Geology 26: 519-522.
Pedros a Soares AC, Noce CM, Wiedemann CM And Pinto CP. 2001. The Araçuaí-West-Congo Orogen in Brazil: an overview of a confined orogen formed during Gondwanaland assembly. Precamb Res 1-4: 307-323.

Schoвbenhaus C. 1996. As trafrogêneses superpostas Espinhaçoe Santo Onofre, Estado da Bahia: Revisão e novas propostas. Rev Bras Geocienc 4: 265-276.

Schobbenhaus C, Campos DA, Derze GR And Asmus HE. 1981. Mapa Geológico do Brasil e da Área Oceânica Adjacente, Incluindo Depósitos Minerais, Escala 1:250.000, DNPM, Brasília.

SILVA LC ET AL. 2002. Reavaliação da evolução geológica em terrenos pré-cambrianos brasileiros com base em novos dados U-Pb SHRIMP, Parte II: Orógeno Araçuaí, Cinturão Mineiro e Cráton do São Francisco Meridional. Rev Bras Geocienc 32: 513528.

TACK L, Wingate MTD, Liégeois JP, Alonso MF AND DEBlond A. 2001. Early Neoproterozoic magmatism (1000-910 Ma) of the Zadinian and Mayumbian Groups (Bas-Congo): onset of Rodinia rifting at the western edge of the Congo craton. Precamb Res 1-4: 277-306.

TeiXeira W. 1993. Avaliação do acervo de dados geocronológicos, isotópicos do Cráton do São FranciscoImplicações tectônicas. In: DoMINGUEZ JML AND Misi A (Eds), O Craton do São Francisco, Salvador: SBG/SGM/CNPq, p. 11-33.

TeiXeira W And Figueiredo MCH. 1991. An outline of Early Proterozoic crustal evolution in the São Francisco craton, Brazil: a review. Precamb Res 53: $1-22$.

Trompette R. 1994. Geology of Western Gondwana (2000-500 Ma). Pan-Anfrican-Brasiliano Agregation of South America and Africa. Balkema, Rotterdam, 350 p.

Trompette R, Ulhein A, Silva ME And KarMANN I. 1992. O Cráton brasiliano - uma revisão. Rev Bras Geocienc 4: 481-486.

Turpin L, Maruèjol P And Cuney M. 1988. U$\mathrm{Pb}, \mathrm{Rb}-\mathrm{Sr}$ and $\mathrm{Sm}-\mathrm{Nd}$ chronology of granitic basement, hydrotermal albitites and uranium mineralization, Lagoa Real, South Bahia, Brazil. Contrib Min Petr 98: 139-147. 
Uhlein A, Trompette RR and Alvarenga CJS. 1999. Neoproterozoic glacial and gravitational sedimentation on a continental rifted margin: The Jequitai-Macaubas sequence (Minas Gerais, Brazil). J South Amer Earth Sci 5: 435-451.
Wilson N, MOORBATH S, TAYLOR PN AND BARBOSA JSF. 1988. Archean and Early Proterozoic crustal evolution in the São Francisco Craton, Bahia, Brazil. Chem Geol 70: 146. 